\title{
Inspecting the Reservoir Characteristics of the Burgan Formation of Soroosh Oil Field Applying Rock Typing Methods in the Context of Geological Studies
}

\author{
Davar Ebrahimi', Abdolhossein Amini², Elham Hajikazemi³ ${ }^{3}$ Ali Solgi1 \\ ${ }^{1}$ Department of Geology, Science and Research Branch, Islamic Azad University, Tehran, Iran \\ ${ }^{2}$ Department of Geology, University of Tehran, Tehran, Iran \\ ${ }^{3}$ Department of Geology Studies, Iranian Offshore Oil Company, Tehran, Iran \\ Email: ahamini@gmail.com
}

How to cite this paper: Ebrahimi, D., Amini, A., Hajikazemi, E. and Solgi, A. (2017) Inspecting the Reservoir Characteristics of the Burgan Formation of Soroosh Oil Field Applying Rock Typing Methods in the Context of Geological Studies. Open Journal of Geology, 7, 488-504.

https://doi.org/10.4236/ojg.2017.74034

Received: February 8, 2017

Accepted: April 27, 2017

Published: April 30, 2017

Copyright (c) 2017 by authors and Scientific Research Publishing Inc. This work is licensed under the Creative Commons Attribution International License (CC BY 4.0).

http://creativecommons.org/licenses/by/4.0/

\begin{abstract}
The Albian age Burgan Formation is one of the most important siliciclastic reservoirs in the Arabian Plate. Northwest of Persian Gulf is the main area in Iran invaded by these siliciclastic sediments. This study uses a new and comprehensive procedure to identify the reservoir characteristics of the Burgan Formation in Soroush oil field (NW Persian Gulf). Results from core and petrographic studies led identification of 7 microfacies (MF1 to MF7) that are grouped into 3 main facies association (FA1, to FA3). Results from reservoir characterization indicate a dramatic decrease in reservoir quality from bottom to top (FA1 toward FA3). Using the Flow Zone Indicator (FZI) method, 5 Hydraluic flow units (HFUs) were recognized in the formation. The HFUs are in a notable accordance with facies associations. The HFUs 1 and 2 correlate with theFA1, the HFUs 3 and 4 with the FA2 and the HFU5 cover intervals defined by FA3. Cluster analysis of wireline logs resulted in determination of 5 electrofacies (EF1 to EF5) which are in agreement with the ascertained HFUs. Inspecting the vertical distribution of FAs, HFUs and EFs, three distinct zones are determined. The lower zone is characterized by good reservoir quality, abundance of FA1, HFUs1 and 2 and also EFs 1 and 2 is observed there. The middle zone with a moderate reservoir quality and upper zone presents the poorest quality. In the middle zone FA2, HFUs 3 and 4 and also EFs 3 and 4 are more abundant while in the upper one interval are clearly correlated with FA3, HFU5 and also EF5.
\end{abstract}

\section{Keywords}

Soroosh Oil Field, Burgan Formation, Hydraulic Flow Units, NW Persian Gulf 


\section{Introduction}

Rock typing is a technical procedure in hydrocarbon reservoir characterization and classifying rocks based on their petrophysical properties for reservoir modelling purposes [1]. Determined rock types contain similar porosity, permeability, capillary pressure and dynamic behavior [1]. Rock typing is usually conducted primarily on core plugs and thin sections prepared from the cores. However, ignoring the geological controls such as pore space evolution is caused by the focus on grouping samples with consistent petrophysical properties, rather than geological characteristics. It is also problematic to achieve a fit-for-purpose rock-typing scheme separate from the influence of diagenetic processes on characteristics such as rock petrophysic, hydrocarbon recovery efficiency and fluid in-place volumes [1] [2] [3] [4] and [5]. Integrating large scale dynamic data to the wireline scale (small scale) is another inevitable challenge. In addition, the difficulties of finding reservoir quality trends at inter-well scales bring up doubts on the efficacy of reservoir rock-typing and simulation [6]. Study of reservoir units is associated with technical terms such as facies, lithofacies, petrofacies, rock types, hydraulic flow units and electrofacies which all are well defined in the literature ([7]-[13]). Determination of hydraulic flow units (HFUs) and electrofacies (EFs) are two common methods in the analysis of reservoir quality, fluid flow, and depositional environment [14] and [15]. Finding a geological framework and integrating the determined rock types can be useful and practical in reservoir characterization. This study aims to determine the standard geological units (facies) of the Burgan Formation and their distribution order in time. Determination of hydraulic fluid units (HFUs) electrofacies (EFs) and their correlation with geological facies are also proposed to present an integrated approach in reservoir characterization.

\section{Geological Setting}

The studied field is located in NW of the Persian Gulf: about $80 \mathrm{~km}$ west of Kharg Island, in which oil is mainly produced from the Albian Burgan Formation [16]. The Persian Gulf is divided to 5 zones based on the strartgraphic, structural and petroleum systems (Figure 1) and the studied field is located in the most prolific area. During the Albian time, Persian Gulf was a part of Neo-Tethys Ocean in which significant carbonate dominated successions were developed by steadily subsiding basement [17] [18] [19] and [20].

In the south of Iran, a carbonate platform [21] was developed during the Cretaceous which deeper part centered in northwest (Lurestan). Periodical inputs from the land (west and southwest) is found responsible for development of deltaic deposits (Zubair and Burgan) in the NW margin of Arabian Plate [17]. Development of the studied Formation in Iran (equivalent to the NahrUmr Formation in Iraq and the Burgan Formation in Kuwait) is related to distal subenvironmets of the deltaic systems [17]. This setting can significantly affect the present characteristics of Kazhdumi deposited in the Soroosh Oilfield. Southwestern area of the Arabian Plate played as a provenance for clastic sediments 


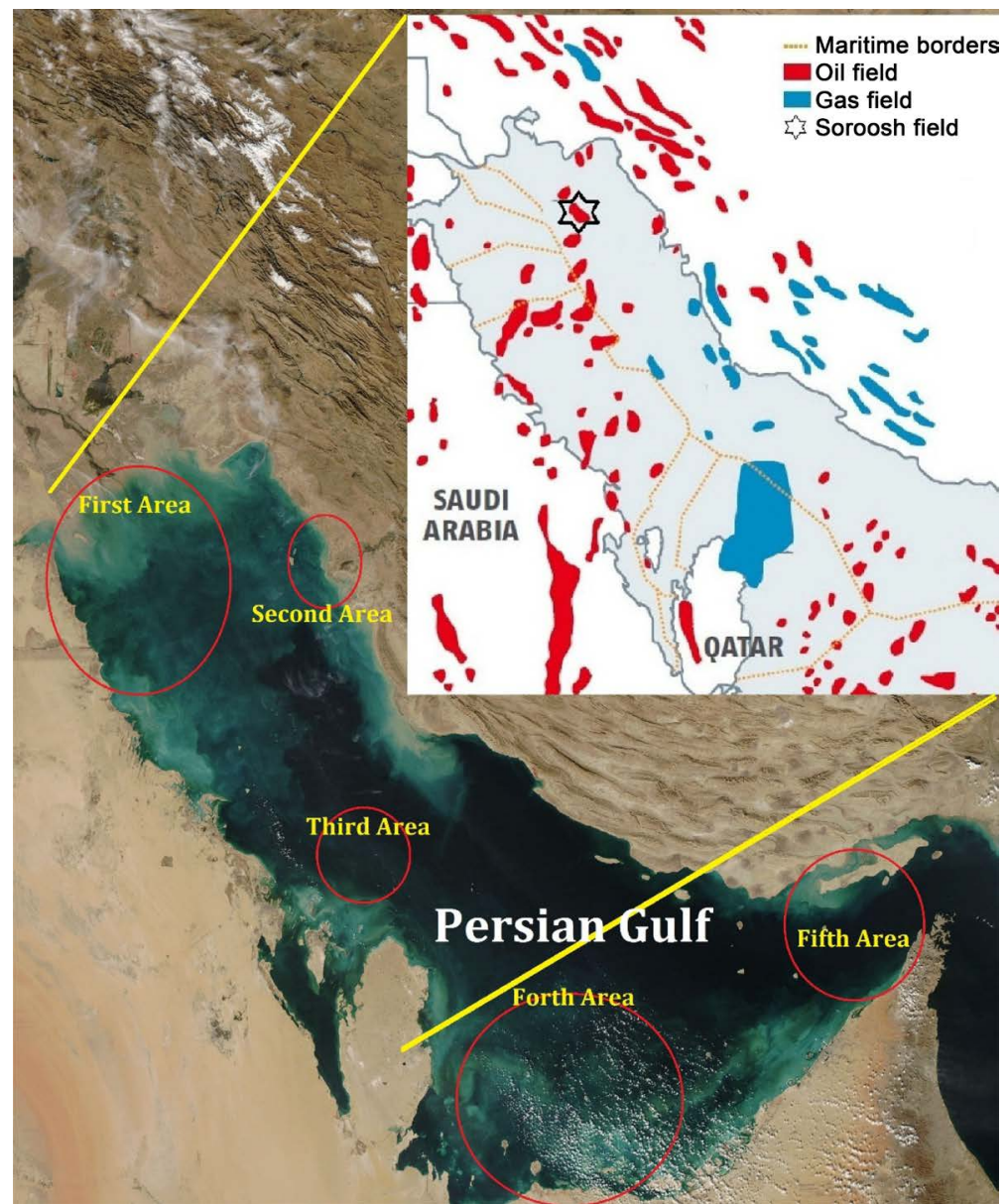

Figure 1. Location of the studied field in Persian Gulf (21).

entered Neo-Tethys during Albian time [20]. Some Arabian and Iranian hydrocarbon fields are located within this charge area and are influenced by siliciclastic inputs.

\section{Stratigraphy}

In the Iranian nomenclature the lower sandstone bearing intervals of the Kazhdumi Formation is known as Burgan Formation [16]. The Kazhdumi Formation is stratigraphically located between the Aptianage Dariyan and the Turonianage Sarvak formations. The Kazhdumi Formation is thetime equivalent of plantbearing deltaic sandstone and shale of the Burgan Formation in Kuwait and the NahrUmr Formation in Iraq [22] [23] and [24]. The Albian sandstones of the Arabian plate show a wide variety of thicknesses in different parts from $390 \mathrm{~m}$ in the east of Kuwait [22] to less than 100 meters in Iranian oil fields. It is mainly considered as a prolific source rock in lots of Iranian hydrocarbon fields [16]. The mentioned thickness oscillations can also be considered as a signature for the Kazhdumi Formation reservoir changes. In other words, these changes originate from depositional setting nature.

The studied units (sandstone bearing intervals presenting good almost good reservoir quality) are equivalent to lower part of the Kazhdumi Formation in 
northwest of the Persian Gulf [22] [25] and [26] and upper part of Burgan in northern Kuwait [27]. The Burgan Formation in its type section (Burgan oil field of Kuwait) is divided into A, B and C zones with total thickness of about 368 meters [28]. B zone shows the least thickness values (20 - 30 meters) but its reservoir quality is far more than other two zones and is introduced as a prolific sandstone interval. In the NW Persian Gulf the Burgan Formation is dominated by sandstone and shale layers and shows similarity to the zone B in Kuwait, where shows the best reservoir quality [28].

As Figure 2 represents, sandstones in the studied field rests on top of the Dariyan Formation (equivalent of Shuaiba Formation in Saudia Arabia) and is overlain by Dair carbonates.

\section{Materials and Methods}

Main data for this study came from the major well of the Soroosh oilfield (Well SRX). A wide variety of data including cores (147 meters), thin section prepared from the cores (450 samples), core porosity and permeability values (310 measurements) and wireline logs are used. A detailed description of the cores and the thin sections carried out to characterize the depositional facies and paleoenvironmental condition of the formation. Both macroscopic and microscopic criteria such as grain size, structures, texture, and fossil content, bedding nature, pore types and diagenetic features are used for the facies analysis. Facies with similar sedimentological characteristics are grouped as a facies association following Flugel 2004 [29]. Porosity and permeabilityof the facies (measured on the core samples) are also inspected for their reservoir characterization.

The hydraulic flow units are determined using numerical methods and based on the core porosity and permeability. The electrofacies are determined using logs. Using numerical methods such as hydraulic flow unit determination and electrofacies all the properties of Burgan are appraised in order to discriminate zones based on the reservoir quality changes. Details of these methods are dis-

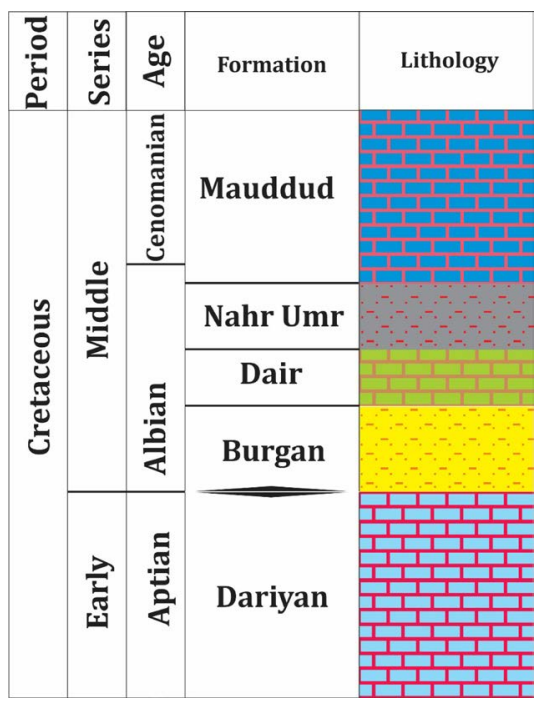

Figure 2. Stratigraphy and general lithology of Cretaceous interval in the studied field. 
cussed in the following sections. This workflow paves the way for a comprehensive and integrated reservoir quality study on a susceptible reservoir rock.

A framework containing geological to electrical studies is performed in the present research. It is tried to find the relationship between geological rock units (microfacies and facies associations) with hydraulic ones (HFUs) and electrical facies (EFs). Exerting this framework and trend, descriptive and quantitative studies are integrated to decipher the most comprehensive reservoir units.

\section{Depositional Facies}

Facies determination is done based on the results from core description and petrographic studies. In this regard, 7 depositional facies are discriminatednamely: Rooted silty mudstone (F1); organic rich quartzarenite (F2); cross-bedded quartzarenite (F3); bioturbated fine sandstone (F4); ooliticironstone (F5); fine laminated mudstone (F6); and Orbitolinabioclastsandy packstone (F7). Major characteristics of the facies are presented in Table 1 and Figure 3. Distribution of porosity and permeability values of the facies are also presented (Figure 3). Cross plot of porosity and permeability variations of the facies are illustrated as a cross plot (Figure 4) to decipher the reservoir quality of each microfacies.

The studied facies are classified into 3 facies associations (genetically related facies) based on their comparable sedimentological and environmental remarks which main characteristic are discussed below.

\subsection{Facies Association 1 (FA1)}

This facies association is marked by abundance of thick units' offacies of rooted silty mudstone (F1) and organic rich quartzarenite (F2) and thin interbeds of siltstone and shale. The sandy facies are well sorted and show cross-bedding associated withpaleosol horizons and oxidized zones. This facies association is related to a fluvial system that was periodically affected from marine tides and/or waves. This facies association provides a best reservoir quality (core porosity and

Table 1. General characteristics of determined microfacies of the Burgan Formation in the studied field.

\begin{tabular}{|c|c|c|c|c|c|c|}
\hline $\begin{array}{l}\text { facies } \\
\text { code }\end{array}$ & facies Name & Lithology & Structure & Fauna & Other Characteristics & $\begin{array}{l}\text { Depositional } \\
\text { setting }\end{array}$ \\
\hline F 1 & Rooted Silty Mudstone & Shale & Lamination, plants roots & Plants debris, amber, Coal & Oxidized grains & Delta Plain \\
\hline F 2 & Organic rich Quartzarenite & Sandstone & Massive Lamination & Plants debris, amber, Coal & $\begin{array}{l}\text { Oxidized grains, plan } \\
\text { residuals }\end{array}$ & Delta Plain \\
\hline F 3 & Cross-bedded Quartzarenite & Sandstone & Cross bedding & - & Oxidized grains & Delta Bar \\
\hline F 4 & Bioturbated fine Sandstone & Sandstone & Bioturbation & Foraminifera, Echinoderm & $\begin{array}{l}\text { Burrow, Glauconite, } \\
\text { carbonate debris }\end{array}$ & Delta Front \\
\hline F 5 & Oolitic Ironstone & Ironstone & Bioturbation, Nodule & Foraminifera, Echinoderm & OoiliticFarbric, Siderite & Prodelta \\
\hline F 6 & Fine laminated mudstone & Shale & Lamination & Foraminifera, Echinoderm & Glauconite, Pyrite & Prodelta \\
\hline F 7 & $\begin{array}{l}\text { Orbitolinabioclast Sandy } \\
\text { packstone }\end{array}$ & Limestone & Bioturbation, Stylilite & Orbitolina, Echinoderm & Glauconite & Open Marine \\
\hline
\end{tabular}



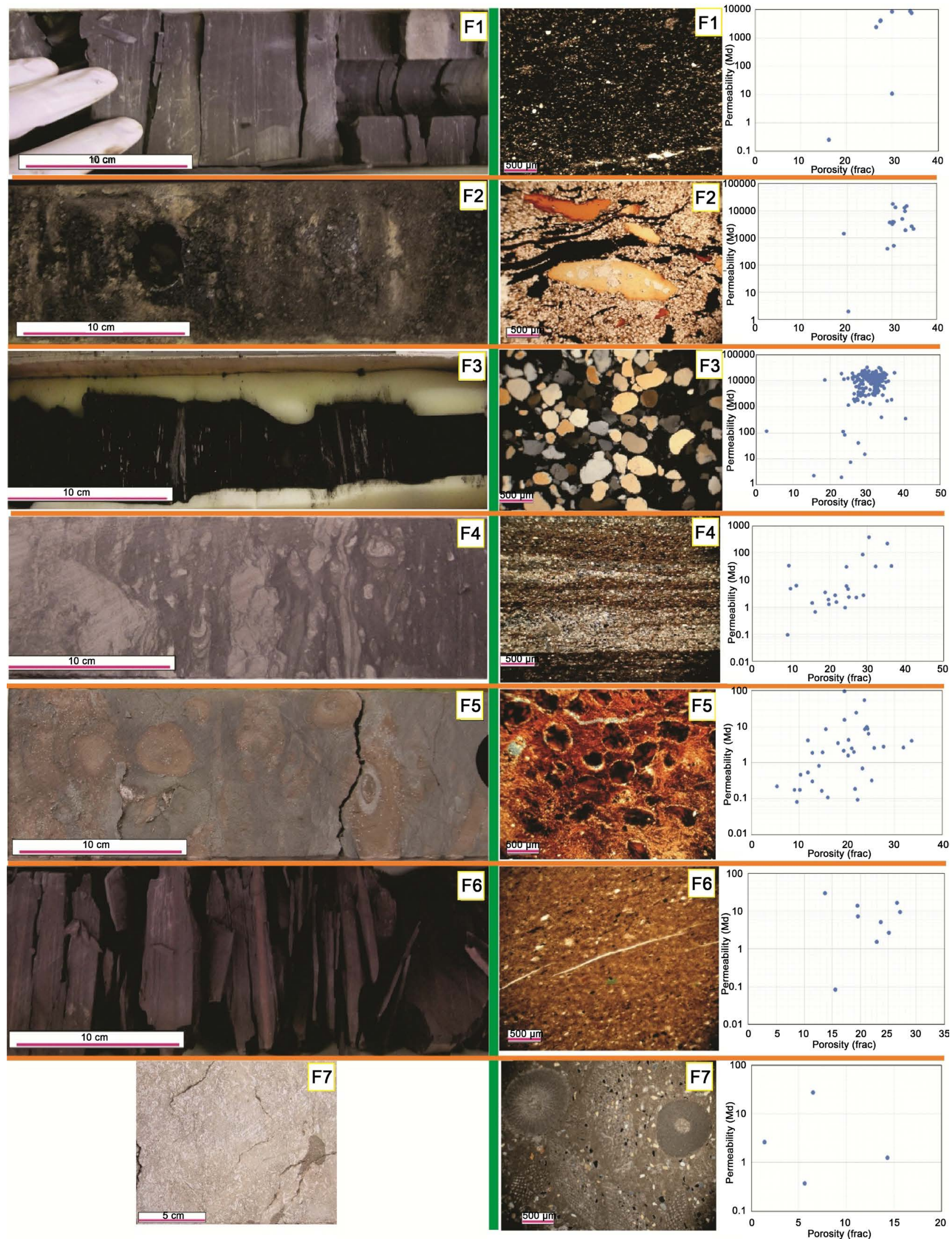

Figure 3. Representative core (left) and thin section photographs (right) of determined microfacies and their porosity andpermeability values. 


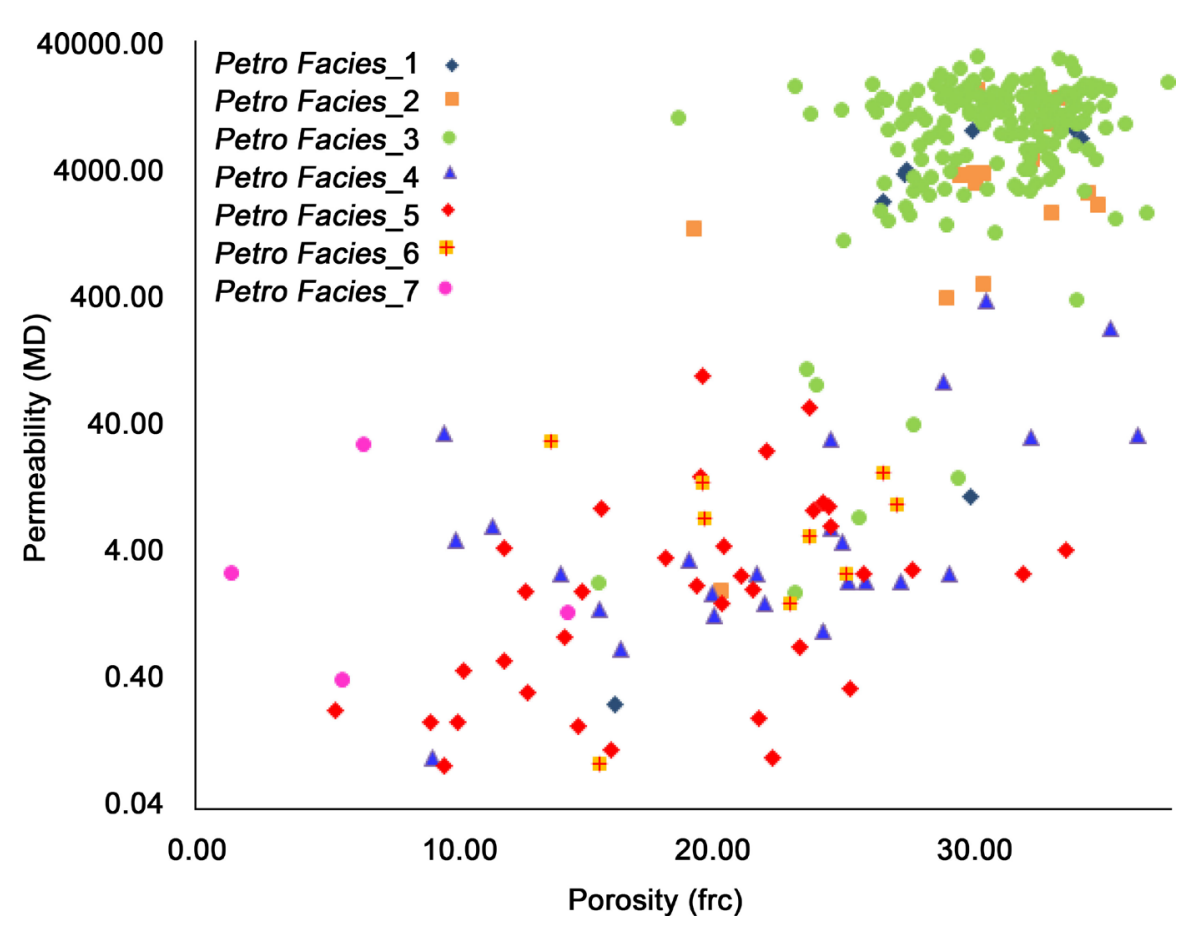

Figure 4. Porosity versus permeability values of the studied microfacies.

permeability) and mostly occurs in the lower partof the studied formation. The porosity values in this facies association reaches up to $40 \%$ in some intervals.

\subsection{Facies Association 2 (FA2)}

Two microfacies deposited in the delta front setting (F3 and F4) are components of this facies association. The first microfacies is formed in the mouth bar zone of delta front (conjunction of the marine realm and fluvial). It shows cross bedding structure and high sorting texture which mainly originate from the high energy level in depositional setting. The sedimentary components constituting F3 are mainly provided by streams; meanwhile one of the marine factors (i.e., wave) dominates their distribution and deposition. Another microfacies of FA2 (F4) is deposited in the seaward zone of the delta front, in the other words, in the lower parts of the delta slope. Fine sandstone lithology of the FA2 presents intense bioturbation are documented as the major component.

\subsection{Facies Association 3 (FA3)}

Fine particles and lamination which observed frequently in FA5, FA6 and FA7, are the major feature of this facies association components. The FA3 is marked by sedimentary features that are related to a deep zone of the Burgan Formation depositional setting. Documentation of characteristics such as glauconite, pyrite, and organi-rich facies (dark/grey color) existence implicate the reduction condition for FA3. The least core porosity and permeability values are recorded here implicating low reservoir quality condition (Figure 5).

Figure 5 summarizes all the characteristics of the studied interval from Burgan Formation. It depicts both the diagenetic and depositional features. Based 


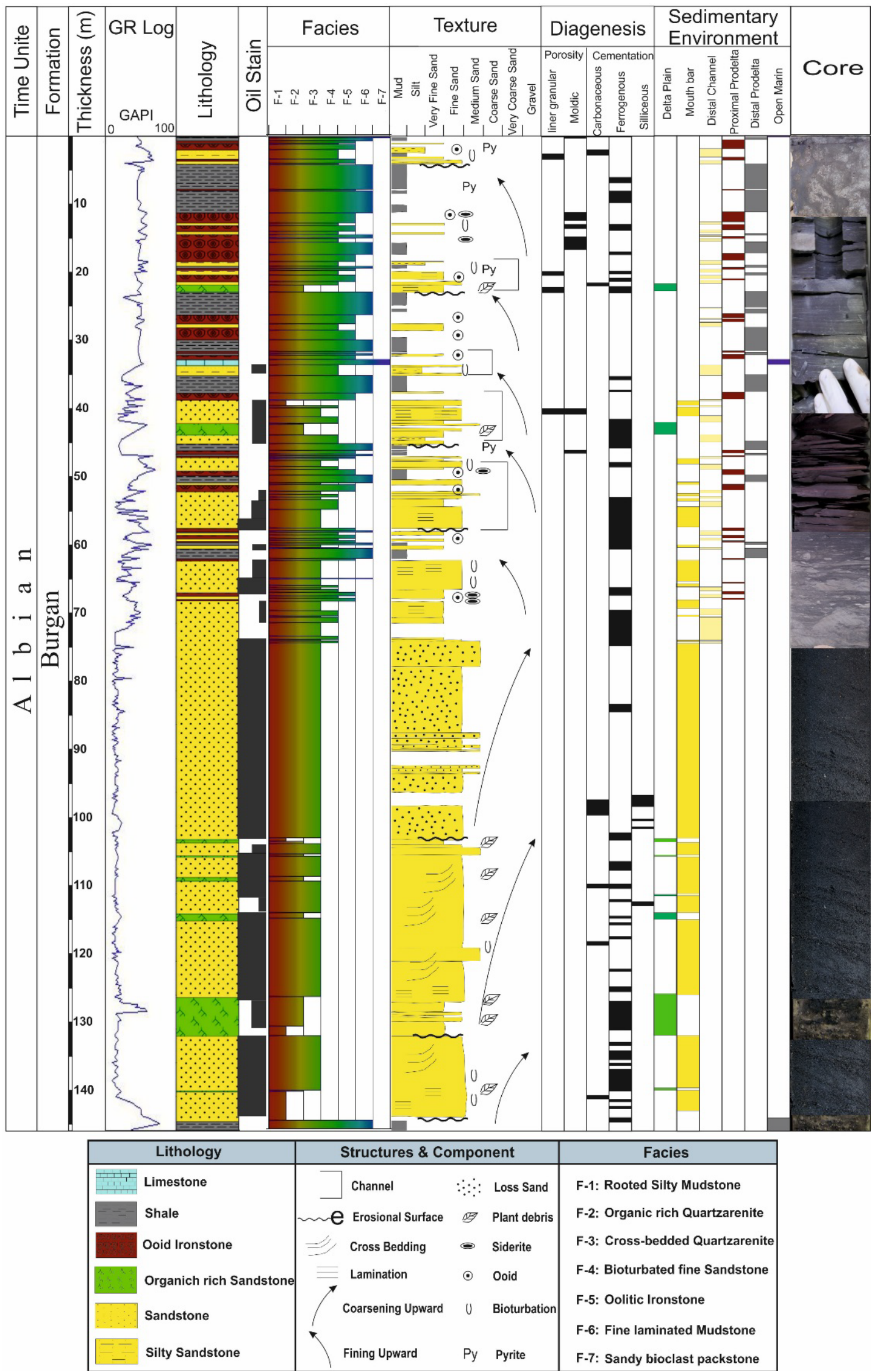

Figure 5. Sedimentological log of the studied interval representing the occurrence of constituent facies and facies associations. 
on it, two main pore types are distinguished: intergranular and moldic which are mainly found in the upper intervals. As mentioned earlier, the sandstone formed in the lower parts is almost loose and this trait prevents the generation of the pores.

\section{Hydraulic Flow Units (HFU)}

Flow units of reservoirs show lateral and vertical continuity in their flow and bedding characteristics and can be practical for classifying a reservoir to distinctive zones (geobodies) with unique flow regime [30] and [31]. These units represent reservoir heterogeneity from well to field scales [11]. A wide variety of methods are introduced for revealing the flow units in the reservoirs such as Flow Zone Indicator (FZI), Modified Lorenz Plot, and Winland [2] [8] [32] [33] [34] [35] [36] that the first is used here.

\section{Flow Zone Indicator (FZI)}

The foundation of this method is based on the relation between core-derived porosity and permeability. Its theory is based on the fact that the fluid flow can be deciphered in the capillary pipes ([9] and [33]). Merging the Darcy and Poiseulle Laws for direct pipes, the conditions of the rock throats are simplified. The FZI is calculated by following equations [33]:

$$
\begin{gathered}
\varnothing_{z}=\frac{\left(\varnothing_{e}\right)}{\left(1-\varnothing_{e}\right)} \\
R Q I=0.0314 \sqrt{\frac{K}{\varnothing_{e}}} \\
F Z I=\frac{R Q I}{\varnothing_{e}}
\end{gathered}
$$

In which, $\varnothing_{e}$ is effective porosity, $\varnothing_{z}$ represents normalized effective porosity, $K$ is permeability in milidarcy and $R Q I$ is rock quality index.

The calculated values of FZI in the Burgan Formation and the methods applied to pick the HFUs are shown in Figure 6. Distribution of the normal probability of the FZI logarithmic values and the dendrogarm presenting the hierarchical tree of this data strongly confirm the actual numbers of the HFUs. Based on these analyses, five associations (or technically, HFUs) are determined. In Figure 6(a) (normal probability distribution of FZI logarithmic) breaks in the plot are considered as boundaries between classes. Practically, line slop changes manifest the separation of populations (HFUs in this case). Figure $6(\mathrm{~b})$ is the dendrogram of FZI data and various numbers of classes are presented in this picture. In the first layer two classes (branches) are involved and in lower one the number of classes' increases. The optimum number of classes (or cut-off) is found in the places that have the most distance (difference) within specified classes. Regarding presented dendrogram, in the case of having 5 classes (branches), the distance between them is the most. The FZI values decrease from the HFU1 toward the HFU5.

Relation between these HFUs and core-based porosity and permeability is 

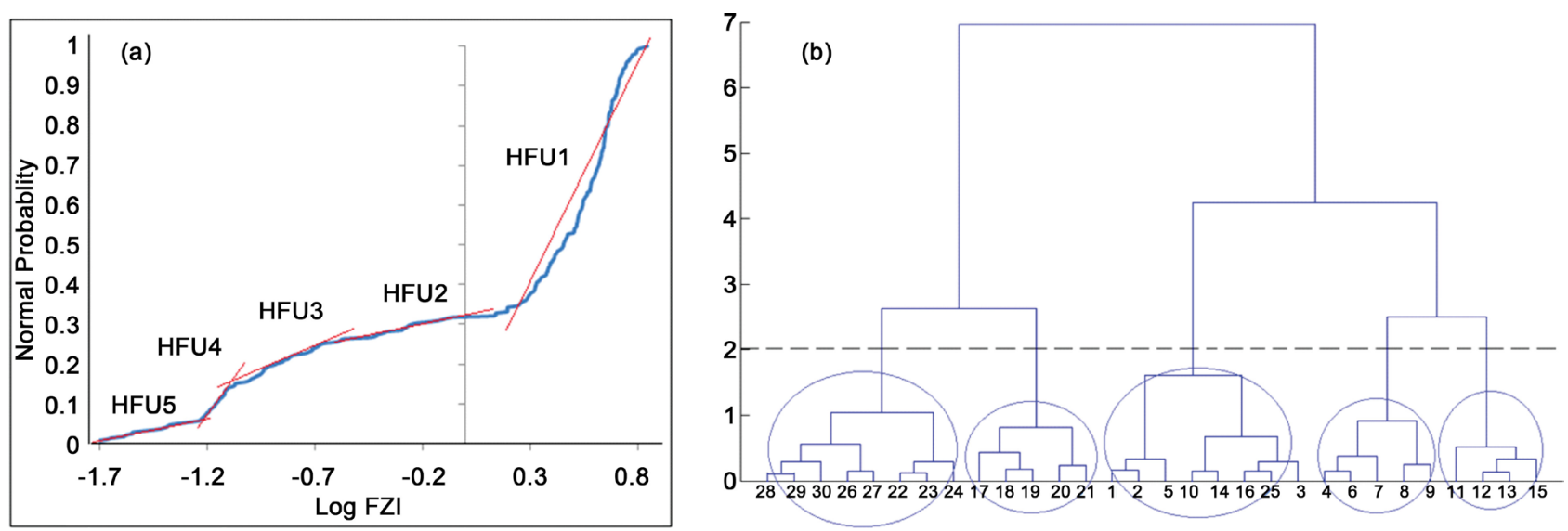

Figure 6. Normal probability plot and dendrogram for the determining HFUs.

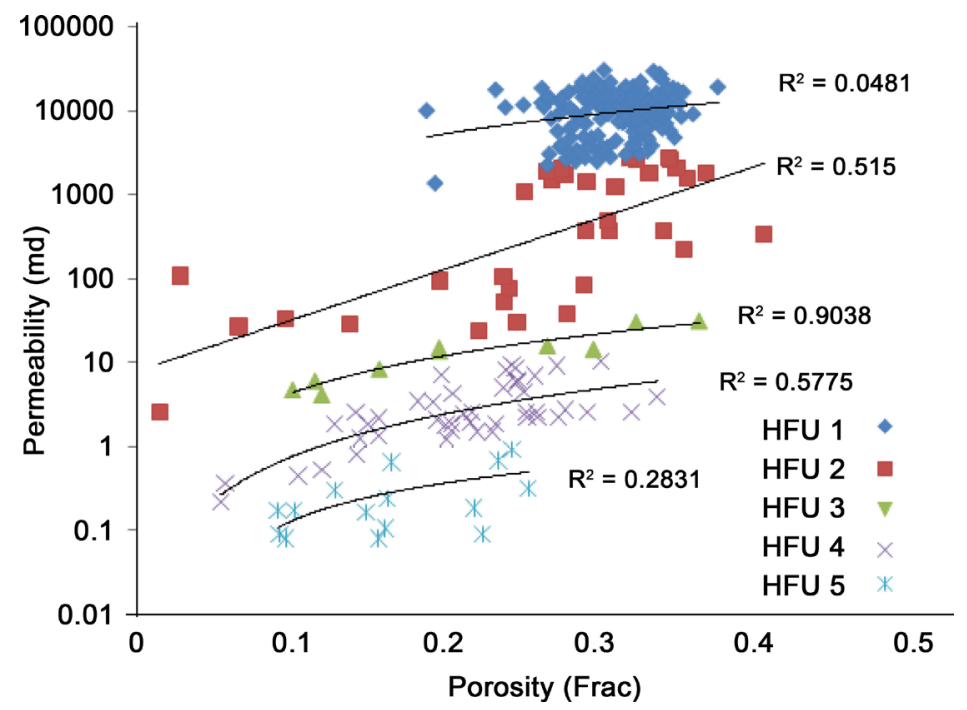

Figure 7. Core-based porosity and permeability relationship in the identified HFUs.

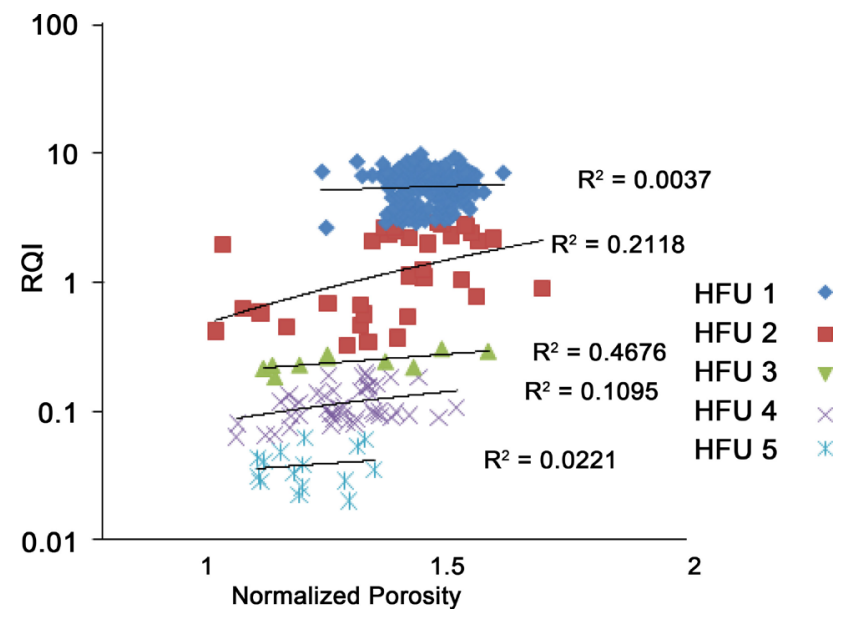

Figure 8. Higher RQI values in the HFU 1 and HFU 2 confirm their higher reservoir quality.

presented in Figure 7. A decreasing trend is obvious in the reservoir quality index from the HFU1 to the HFU5 (Figure 8). This trend can be clearly explained 
by the geologic content of these HFUs. In the following section, after defining continuous EFs and correlating them with HFUs, the relationship between these three reservoir units can be deciphered. Obviously, it seems HFUs 1 and 2 can be more related with FA1 rather than others.

\section{Electrofacies}

The logfacies or electrofacies are sedimentary facies defined by clustering wireline logs [15]. Various statistical methods are used for clustering of the logs, such as K-means, Ascending Hierarchical Clustering, Self-Organizing Map (SOM) and Multi-Resolution Graphic-Base Clustering (MRGC), which the last one is applied in this study.

In the MRGC method data density is evaluated to find probable distribution pattern (Neighboring Index-NI) for the data. The NI can be assessed by the rank of data rather than their distance. This method has some advantages compared to other methods for being a two-step procedure, fast processing, proposing optimum number of clusters to the user, availability of merging and splitting cluster [37].

Considering various methods for selecting input parameters for clustering (such as genetic algorithm [18], principle component analysis [38] [39], etc.) a visual monitoring can present the appropriate variables due to the simplicity of data and limitation of variables. In this regard neutron porosity (NPHI), acoustic transit time (DT), compute gamma ray (CGR) and photoelectric (PEF) logs are selected for this study. The data set seems adequate for determination of both reservoir quality (by NPHI and DT) and lithology (CGR and PEF). Some core measurements are also applied as associated data to decipher the existing trend in the identified electrofacies.

A dendrogram of the electrofacies frequency is established to find the optimum number of associations in the distributed data (Figure 9). Five distinct

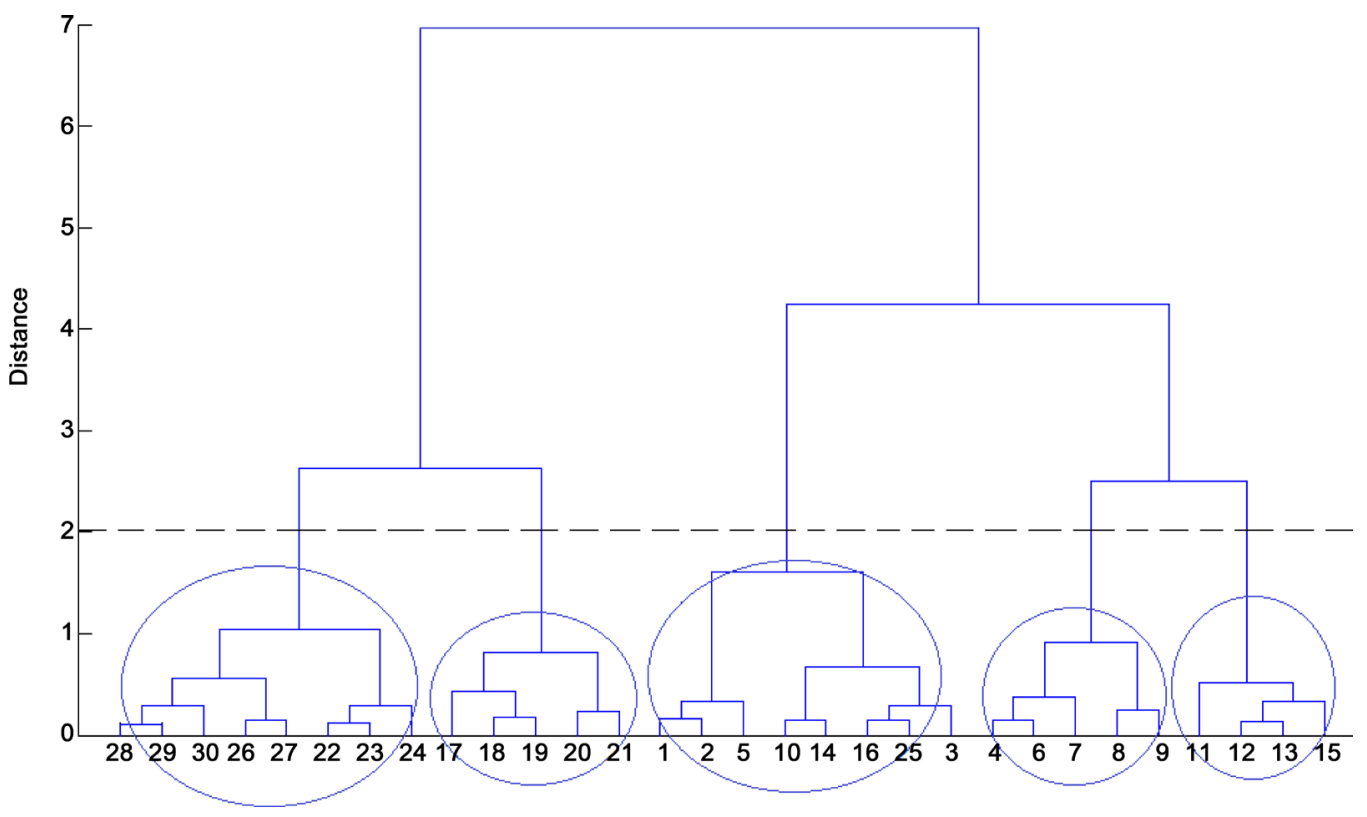

Figure 9. The dendrogram handled for picking the optimal number of clusters. 

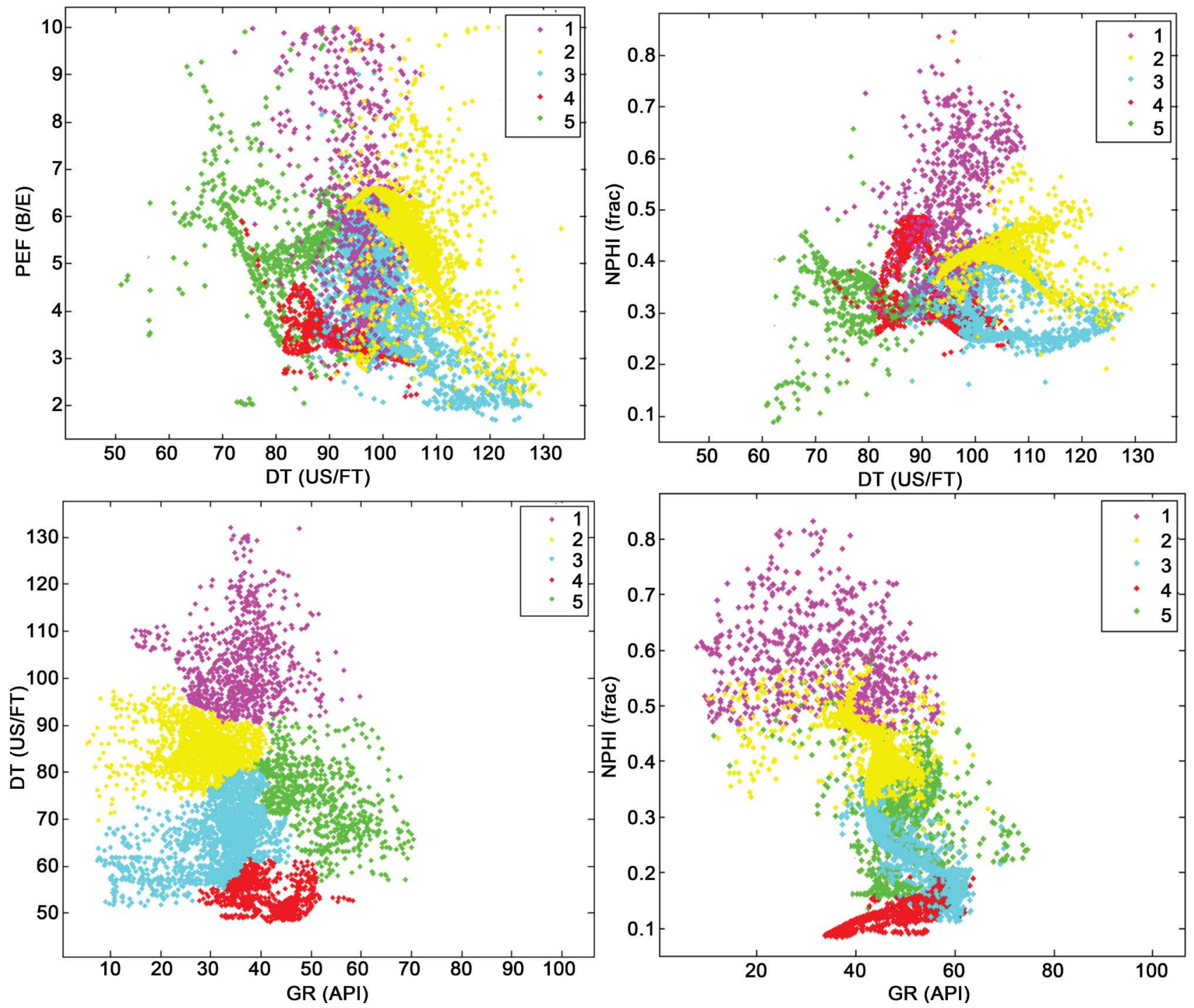

Figure 10. Clustering input wireline logs colored according to the relevant defined elecrofacies.

groups can be discriminated in the dendogram which reservoir characteristics can also be evaluated. Distribution of the input wireline logs is presented and colored based on the identified electrofacies. Nearly accurate and sharp boundary between the clusters is observed. Such a distribution confirms the clustering accuracy and the electrofaices characteristics. EFs 1 and 2 have the high neutron porosity values meanwhile their shale content is also less than others. So, it can be concluded that there is a clear similarity between these two EFs (1 and 2) and HFUs 1 and 2. Core data and their correlated clusters are also illustrated in the Figure 11 after evaluating the EFs; their distribution in other wells is also analyzed.

Distribution of the determined electrofacies in the studied well (Figure 12) depicts a general scheme for reservoir characterization. The intervals containing $\mathrm{EF} 1$ and EF2 (presenting better reservoir quality than other EFs) are in the lower and middle parts and the other EFs with negligible reservoir quality in the upper part. Distribution of EF 1 and EF 2 is in a good accordance with that of HFU 1 and HFU 2 and FA 1. 


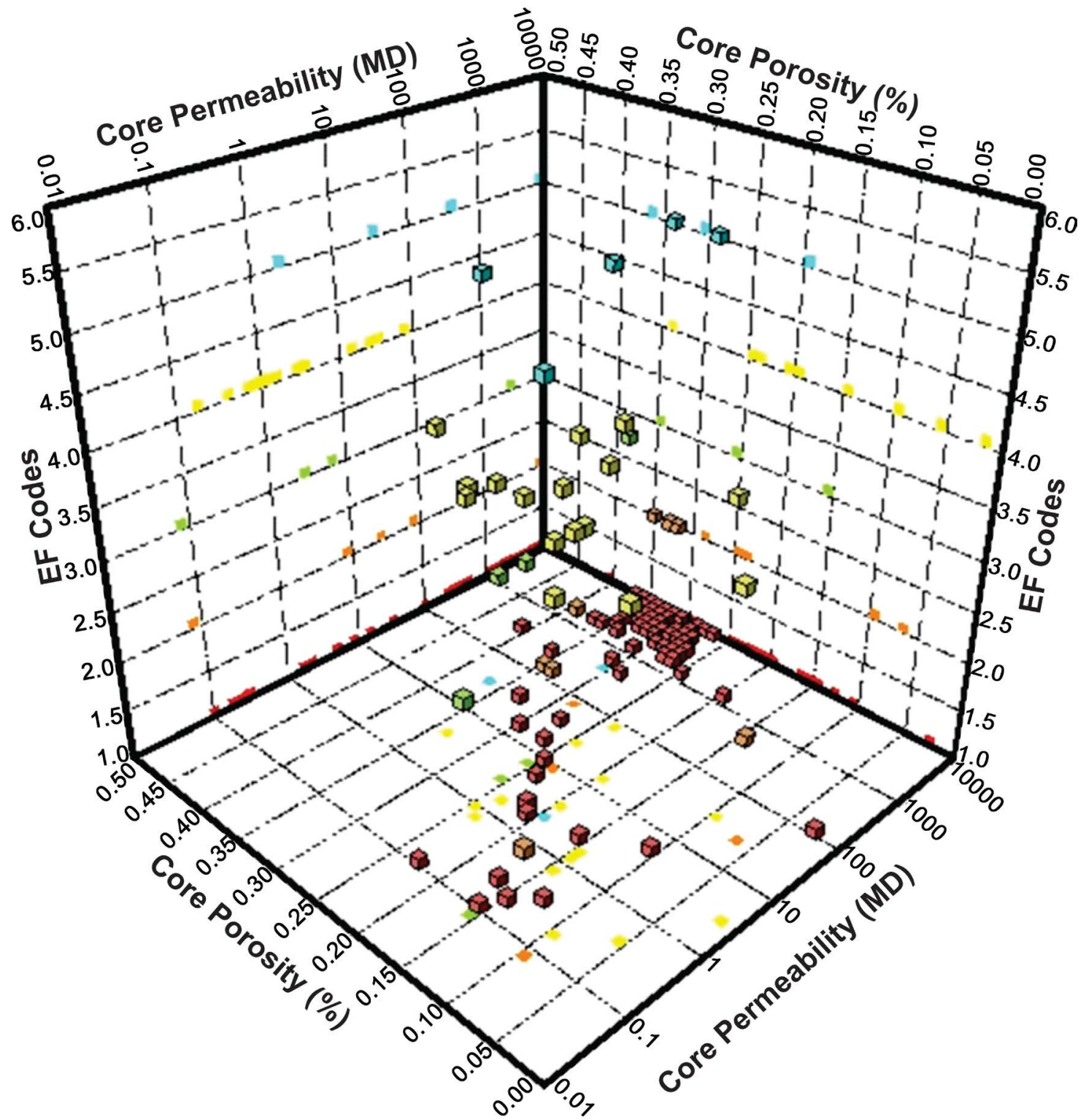

Figure 11. Scatter plot of the core data color coded regarding EFs confirming the decreasing trend in reservoir quality from EF 1 to EF 5.

\section{Conclusion}

This study revealed that there are 3 main facies association with distinct reservoir characteristic: the first one presents the best reservoir quality and contains microfacies 1 to 3 (F1, F2 and F3); the second one presents moderate quality and includes F4 and F5; the last composed of microfacies F6 and F7does not show reservoir quality. FZI also depicted 5 HFUs which their reservoir quality decreases dramatically from HFU 1 to HFU 5. HFU 1 and 2 are comparable to the first facies association which it is more frequent in the lower part of the Burgan Formation in the Soroosh Oilfield. Results of electrofacies analysis reveal their relationship with facies and HFUs. It seems primary depositional environment strongly affected the latter reservoir quality. Units derived from core (HFUs) and wireline logs (EFs) data are clearly comparable with facies association. Con- 


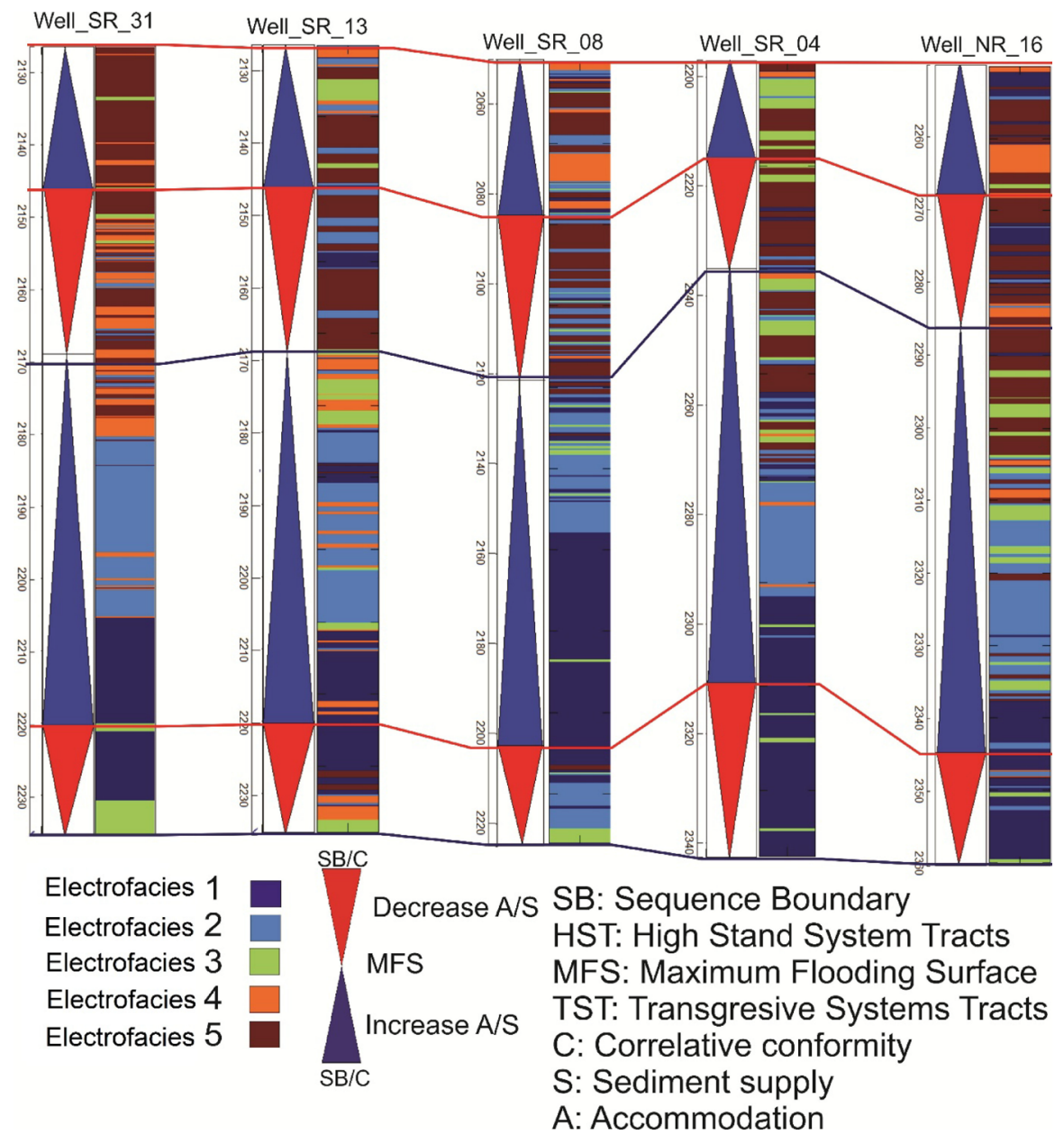

Figure 12. Electrofacies distribution in studied wells.

sequently, the depositional setting control on reservoir quality of the Burgan Formation in Sorrosh Oilfield is confirmed and can be investigated in other locations.

\section{References}

[1] Chandra, V., Barnett, A., Corbett, P., Geiger, S., Wright, P., Steele, R. and Milroy, P. (2015) Effective Integration of Reservoir Rock-Typing and Simulation Using Near-Wellbore Upscaling. Marine and Petroleum Geology, 67, 307-326. https://doi.org/10.1016/j.marpetgeo.2015.05.005

[2] Gomes, J.S., Ribeiro, M.T., Strohmenger, C.J., Negahban, S. and Kala, M.Z. (2008) Carbonate Reservoir Rock Typingethe Link betwen Geology and SCAL. SPE Paper, $118284 \mathrm{p}$.

[3] Hollis, C., Vahrenkamp, V., Tull, S., Mookerjee, A., Taberner, C. and Huang, Y. (2010) Pore System Characterisation in Heterogeneous Carbonates: An Alternative Approach to Widely-Used Rock-Typing Methodologies. Marine and Petroleum Geology, 27, 772-793. https://doi.org/10.1016/j.marpetgeo.2009.12.002

[4] Skalinski, M. and Kenter, J.A.M. (2015) Carbonate Petrophysical Rock Typing: Integrating Geological Attributes and Petrophysical Properties while Linking with Dynamic Behaviour. Fundamental Controls on Fluid Flow in Carbonates: Current Workflows to Emerging Technologies, 406, 229-259. 
https://doi.org/10.1144/sp406.6

[5] Van der Land, C., Wood, R.A., Wu, K., van Dijke, M.I.J., Jiang, Z., Corbett, P.W.M. and Couples, G.D. (2013) Modelling the permeability evolution of carbonate rocks. Marine and Petroleum Geology, 48, 1-7. https://doi.org/10.1016/j.marpetgeo.2013.07.006

[6] Agar, S.M. and Geiger-Boschung, S. (2015) Fundamental Controls on Fluid Flow in Carbonates. In: Agar, S., Geiger, S., Eds., Current Workflows to Emerging Technologies, Geological Society special publication, Geological Society of London, London, 1-59

[7] Dorfman, M.H., Newey, J.J., and Coats, G.R. (1990) New Techniques in Lithofacies Determination and Permeability Prediction in Carbonates Using Well Logs. In: Hurst, A., Lovell, M.A. and Morton, A.C., Eds., Geological Applications of Wireline Logs, Geological Society, London, 113-120. https://doi.org/10.1144/gsl.sp.1990.048.01.10

[8] Gunter, G., Finneran, J., Hartmann, D. and Miller, J. (1997) Early Determination of Reservoir Flow Units Using an Integrated Petrophysical Method, SPE 38679.

[9] Porras, J.C., Barbato, R. and Khazen, L. (1999) Reservoir Flow Units: A Comparison Between Three Different Models in the Santa Barbara and Pirital Fields, North Monagas Area, Eastern Venezuela Basin, SPE Latin American and Caribbean Petroleum Engineering Conference, Caracas, 21-23. https://doi.org/10.2118/53671-MS

[10] Reading, H.G. and Collinson, J.D. (1996) Clastic Coasts. In: Reading, H.G., Ed., Sedimentary Environments. Process, Facies and Stratigraphy, Blackwells, 154-231.

[11] Ebanks, W., Scheihing, M. and Atkinson, C. (1992) Flow Units for Reservoir Characterization. In: Thompson, M.D. and Woods, A.M., Eds., Development Geology Reference Manual, AAPG Methods in Exploration Series, 10, 282-284.

[12] Rushing, J.A., Newsham, K.E. and Blasingame, T.A. (2008) Rock Typing-Keys to Understanding Productivity in Tight Gas Sands. SPE Unconventional Reservoirs Conference, 10-12 February 2008, Keystone, Colorado. https://doi.org/10.2118/114164-MS

[13] Serra, O. and Abbott, H.T. (1980) The Contribution of Logging Data to Sedimentology and Stratigraphy. SPE-9270-PA. https://doi.org/10.2118/9270-PA

[14] Ebanks, J.W.J. (1987) Flow Unit Concept-Integrated Approach to Reservoir Description for Engineering Projects. AAPG Bulletin, 71(CONF-870606-).

[15] Serra, O. (1986) Fundamentals of Well Log Interpretation. The Interpretation of Logging Data, Developments in Petroleum Science, Elsevier, Amsterdam, 684 p.

[16] Motiei, H. (1993) Stratigraphy of Zagros. In: Hushmandzadeh, A., Ed., Treatise on the Geology of Iran, Geological Survey of Iran Press, Tehran.

[17] Murris, R.J. (1980) Middle East: Stratigraphic Evolution and Oil Habitat. AAPG Bulletin, 64, 597-618.

[18] Berberian, M. and King, G.C.P. (1981) Towards a Paleo-Geography and Tectonic Evolution of Iran. Canadian Journal of Earth Sciences, 18, 210-265. https://doi.org/10.1139/e81-019

[19] Setudehnia, A. (1978) The Mesozoic Sequence in South-West Iran and Adjacent Areas. Journal of Petroleum Geology, 1, 3-42. https://doi.org/10.1111/j.1747-5457.1978.tb00599.x

[20] Ziegler, M.A. (2001) Late Permian to Holocene Paleofacies Evolution of the Arabian Plate and Its Hydrocarbon Occurrences. GeoArabia, 6, 445-504.

[21] Al-Fares, A.A., Bouman, M. and Jeans, P. (1998) A New Look at the Middle to 
Lower Cretaceous Stratigraphy, Offshore Kuwait. GEO Arabia, 3, 543-560.

[22] Alsharhan, A.S. and Nairn, A.E.M. (1997) Sedimentary Basins and Petroleum Geology of the Middle East. Elsevier, Netherlands.

[23] Ibrahim, M.I.A. and Al-Hitmi, H.H.A. (2000) Albian-Cenomanian Palynology, Paleoecology and Organic Thermal Maturity of Well DK-B in the Dukhan Oil Field of Western Qatar. GeoArabia, 5, 483-508.

[24] Alavi, M. (2004) Regional Stratigraphy of the Zagros Fold-Thrust Belt of Iran and Its Proforeland Evolution. American Journal of Science, 304, 1-20.

https://doi.org/10.2475/ajs.304.1.1

[25] Bordenave, M.L. and Burwood, R. (1990) Source Rock Distribution and Maturation in the Zagros Belt; Provenance of the Asmari and Bangestan Reservoir Oil Accumulations. Organic Geochemistry, 16, 369-387. https://doi.org/10.1016/0146-6380(90)90055-5

[26] Al-Eidan, A.J., Wethington, W.B. and Davies, R.B. (2001) Upper Burgan Reservoir Distribution, Northern Kuwait: Impact on Reservoir Development. GeoArabia, 6, 179-208.

[27] Strohmenger, C.J., Patterson, P.E., Al-Sahlan, G., Mitchell, J.C., Feldman, H.R., Demko, T.M., Wellner, R.W., Lehmann, P.J., McCrimmon, G.G., Broomhall, R. W. and Al-Ajmi, N. (2006) Sequence Stratigraphy and Reservoir Architecture of the Burgan and Mauddud Formations (Lower Cretaceous). In: Harris, P.M. and Weber, L.J., Eds., Giant hydrocarbon reservoirs of the world: From rocks to reservoir characterization and modeling, AAPG Memoir 88/SEPM Special Publication, Kuwait, 213-245.

[28] Owen, R.M.S. and Nasr, S.N. (1958) Stratigraphy of the Kuwait-Basra Area. In: Weeks, L.G., ed., Habitat of Oil, AAPG.

[29] Flügel, E. (2004) Microfacies of Carbonate Rocks. Springer, Heidelberg. https://doi.org/10.1007/978-3-662-08726-8

[30] Hearn, C.L., Ebanks Jr., W.J., Tye, R.S. and Ranganathan, V. (1984) Geological Factors Influencing Reservoir Performance of the Hartzog Drawfield. Journal of Petroleum Technology, 36, 1335-1344. https://doi.org/10.2118/12016-PA

[31] Bhattacharya, S., Byrnes, A.P., Watney, W.L. and Doveton, J.H. (2008) Flow Unit Modeling and Fine-Scale Predicted Permeability Validation in Atokan Sandstones: Norcan Eastfield, Kansas. AAPG Bulletin, 92, 709-732. https://doi.org/10.1306/01140807081

[32] Winland, H.D. (1972) Oil Accumulation in Response to Pore Size Changes. In: Field, W., Ed., Amoco Production Research Report, Saskatchewan.

[33] Amaefule, J.O., Altnubay, M., Tiab, D., Kersey, D.G. and Keeland, D.K. (1993) Enhanced Reservoir Description: Using Core and Log Data to Identify Hydraulic (Flow) Units and Predict Permeability in Uncored Intervals/wells, 1-16.

[34] Elgaghah, S.A., Tiab, D. and Osisanya, S.O. (2001) Influence of Stress on the Characteristic of Flow Units in Shaly Formations. Journal of Canadian Petroleum Technology, 40, 4. https://doi.org/10.2118/01-04-01

[35] Nooruddin, H.A. and Hossain, M.E. (2012) Modified Kozeny-Carmen Correlation for Enhanced Hydraulic Flow Unit Characterization. Journal of Petroleum Sciences and Engineering, 80, 107-115. https://doi.org/10.1016/j.petrol.2011.11.003

[36] Slatt, R.M. (2006) Stratigraphic Reservoir Characterization for Petroleum Geologists and Engineers. In: Elsevier, A., Ed., Netherlands, 478 p.

[37] Ye, S.J. and Rabiller, P. (2000) A New Tool for Electro-Facies Analysis: Multi-Resolution Graph-Based Clustering. SPWLA 41st Annual Logging Symposium, 
Society of Petrophysicists and Well-Log Analysts.

[38] Whitley, D.A. (1994) genetic Algorithm Tutorial. Statistics and Computing, 4, 6585. https://doi.org/10.1007/BF00175354

[39] Yeung, K.Y. and Ruzzo, W.L. (2001) Principal Component Analysis for Clustering Gene Expression Data. Bioinformatics, 17, 763-774.

https://doi.org/10.1093/bioinformatics/17.9.763

\section{Scientific Research Publishing}

Submit or recommend next manuscript to SCIRP and we will provide best service for you:

Accepting pre-submission inquiries through Email, Facebook, LinkedIn, Twitter, etc. A wide selection of journals (inclusive of 9 subjects, more than 200 journals)

Providing 24-hour high-quality service

User-friendly online submission system

Fair and swift peer-review system

Efficient typesetting and proofreading procedure

Display of the result of downloads and visits, as well as the number of cited articles

Maximum dissemination of your research work

Submit your manuscript at: http://papersubmission.scirp.org/

Or contact ojg@scirp.org 